\title{
Detection of Genetic Variation and Genetic Diversity in Two Indian Mudskipper Species (Boleophthalmus boddarti, B. dussumieri) using RAPD Marker
}

\author{
Vellaichamy RAMANADEVI, Muthusamy THANGARAJ*, \\ Anbazhagan SURESHKUMAR, Jayachandran SUBBURAJ \\ Annamalai University, Centre of Advanced Study in Marine Biology, 608502 Parangipettai, \\ Tamil Nadu, India; coralholder@yahoo.com (*correspondingauthor)
}

\begin{abstract}
Due to the environmental changes and habitat destruction the mudskipper fish population is decreasing in recent years. To predict the fish population structure, frequent manual survey and molecular methods are widely used. Molecular markers such as RAPD, microsatellite, allozyme, D-loop haplotype are frequently adopted to assess the population structure of an organism. In this study tenarbitrary primers were screened to estimate the genetic relationships and diversity of two mudskipper species (Boleophthalmus boddarti and $B$. dussumieri) in Vellar estuary, Tamilnadu, India. By this RAPD marker study, the genetic diversity $(\mathrm{H})$ in $B$. boddarti was more $(0.0116 \pm 0.0066)$ than in $B$. dussumieri $(0.0056 \pm 0.0024)$ in Vellar estuary (India). The genetic distance between $B$. boddarti and $B$. dussumieri was 1.7943 . By observing the species specific bands and the phylogenetic analysis it is revealed that these two species clearly deviated into separate clusters emphasizing the distinct species status.
\end{abstract}

Keywords: Boleophthalmus boddarti, B. dussumieri, genetic diversity, Mudskipper, RAPD

\section{Introduction}

Mudskippers (Gobiidae: Oxudercinae) live in intertidal habitat of the mudflats and in mangrove ecosystem (Murdy, 1989) and these fishes are uniquely adapted to a completely amphibious lifestyle (Graham, 1997). Being amphibious, they are uniquely adapted to intertidal habitats, unlike most fish in such habitats which survive the retreat of the tide by hiding under wet seaweed or in tidal pools (Graham, 1997). Anatomical and behavioural adaptations that allow them to move effectively on land as well as in the water (Harris, 1960). As their name implies, these fish use their fins to move around in a series of skips. They can also flip their muscular body to catapult themselves up to 2 feet $(60 \mathrm{~cm})$ into the air (Piper, 2007). They are found in mangrove ecosystems and mudflats of East Africa and Madagascar east through the Sundarbans of Benga, Southeast Asia to Northern Australia, southeast China and southern Japan, up to Samoa and Tonga Islands (Murdy, 1989). They grow to a length of about $9.5 \mathrm{~cm}$ and are carnivorous opportunist feeder (Murdy, 1989). They feed on small prey such as small crabs and other arthropods (Murdy, 1989). The two mudskipper species such as, Boleophthalmus boddarti and B. dussumieri are the residential fishes inhabiting the mudflats of the Vellar estuary and the waterways of Pichavaram mangrove forests, Tamil $\mathrm{Nadu}$, India. The year 2004 tsunami made rapid changes in the morphology of the mudflats by shifting the dominant soil type-clay rich soil (clay 60\%) into sandy soil (sand 70\%) (Ravi, 2005). Most strikingly, the population of the mudskippers was totally eliminated in some areas and in other areas the population become highly reduced (3 to 12 individuals/sq.m. to 1 to 3 individuals/sq.m. (Ravi, 2005). So it is very essential the periodic manual survey or molecular study to assess the population structure of these declining species in their native habitat.

Random amplified polymorphic DNA (RAPD) analysis is a technique based on the polymerase chain reaction (PCR) amplification of discrete regions of genome with short oligonucleotide primers of arbitrary sequence (Welsh and McClelland, 1990; Williams et al., 1990). The method is simple and rapid technique for determining genetic diversity, variation and no prior knowledge of the genome under study is required (Hadrys et al., 1992). RAPD analysis also has been used to evaluate genetic diversity for species and subspecies identification in guppy (Dinesh et al., 1993), tilapia (Bardakci and Skibinski, 1994; Dinesh et al., 1996), brown trout and Atlantic salmon (Elo et al., 1997), largemouth bass (Williams et al., 1998), Indian major carps (Barman et al., 2003) and damsel fishes (Parveen et al., 2011). But in Indian mudskippers it has not been used so far and there is no such study was explained the population structure of these species. In this study, the genetic diversity was analysed and accessed the 
140

genetic variation in $B$. boddarti and $B$. dussumieri using RAPD marker.

\section{Materials and methods}

\section{Sample collection and DNA isolation}

Tissue samples (fin clips) of B. boddarti and B. dussumieri $(\mathrm{n}=20 /$ species $)$ were collected from Vellar estuary mangroves (Lat 1 1 ${ }^{\circ} 29^{\prime} \mathrm{N}$; Lon $79^{\circ} 46^{\prime} \mathrm{E}$ ) and stored at $95 \%$ ethanol. Genomic DNA was extracted from the stored tissues by proteinase- K, Sodium Chloride based protocol (Taggart et al., 1992). DNA samples from individuals of each species were diluted to $25 \mathrm{ng} / \mu \mathrm{l}$ with deionized distilled water and used for PCR amplification. Ten commercially available decamer random primers $(A n 1-A n 10)$ from Chromous Biotech Pvt Ltd (Bangalore, India) were used for this study.

\section{Polymerase Chain Reaction}

The amplification reaction was carried out in a $25-\mu \mathrm{l}$ reaction volume containing $10 \mathrm{mM}$ Tris- $\mathrm{HCl}, \mathrm{pH} 8.5,50$ $\mathrm{mM} \mathrm{KCl}, 2.5 \mathrm{mM} \mathrm{MgCl}_{2}, 0.001 \%$ gelatin, $100 \mu \mathrm{M}$ each of dATP, dCTP, dGTP, and dTTP, $0.2 \mu \mathrm{M}$ of each primer, $1 \mathrm{U}$ of Taq DNA polymerase (Bangalore Genei, India) and $25 \mathrm{ng}$ of weight genomic DNA. RAPD-PCR was performed in a thermocycler (Lark, India) for 40 cycles consisting of denaturation at $94^{\circ} \mathrm{C}$ for 30 seconds, annealing at $35^{\circ} \mathrm{C}$ for 30 seconds, and extension at $72^{\circ} \mathrm{C}$ for 60 seconds. The final extension was carried out at the same temperature for 5 minutes. The resulting products were electrophoretically analyzed through $1.5 \%$ agarose gels, stained with ethidium bromide, and visualized using a UV transilluminator (Maniatis et al., 1982). Subsequently the gel was photographed using a gel documentation system (Lark, India).

\section{RAPD Data Analysis}

Sizes of RAPD bands were determined by comparison with a 500-bp ladder and genetic similarity/distance between the two fish species was estimated using PopGene Software (Version 1.31, Yeh et al., 1999) Nei and Li's (1979) genetic similarity (GS) among the two species was computed and converted by PopGene into genetic distance (GD) according to Hillis and Mortiz's (1990) formula, GD = 1-GS. The GS reflects the proportion of the bands shared between individuals and values range from (1) when present to $(0)$ when absent.

Phylogenetic relationship based on genetic distance values generated from RAPD data among two species and a dendrogram was also plotted by unweighted pair group method of arithmetic averages (UPGMA) (Sneath and Sokal, 1973) and Nei (1978) NEIGHBOUR procedure of PYLIP (Version 3.5c, Felsenstien, 1993) using PopGene software (Version 1.31, Yeh et al., 1999).

\section{Results}

\section{Genetic variation}

The number of amplified bands observed varied, depending on the primers, species and individuals. All the RAPD profiles obtained in this analysis are shown in Fig. $1 \mathrm{a}, \mathrm{b}$. In general, the number of resolved amplified fragments varied from 3 to 7 , with the size range varying from 30 to $2500 \mathrm{bp}$. On average, each random primer amplified 5.50 bands in B. boddarti, and 4.90 in B. dussumieri (Tab. 1). The total scorable bands were 104 , under which the total numbers of species-specific bands were 74 (Tab. 1).

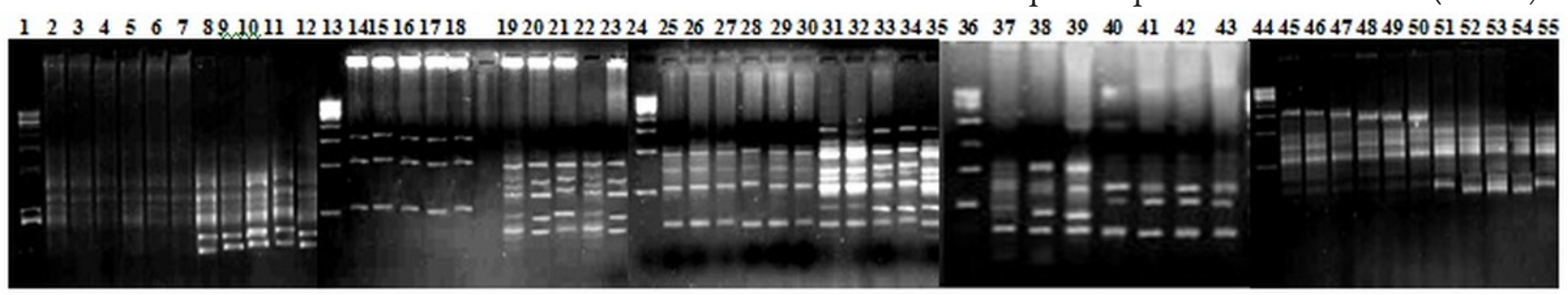

Fig. 1 (a). RAPD profiles generated with arbitrary primers in two mudskipper species with primer (An1-An5) Lanes 1, 13, 24, 36 and 44: 500-bp DNA ladder. Lanes 2-7; 14-18; 25-30; 37-39; 45-50: B. boddarti. Lanes 8-12; 19-23; 31-35; 40-43; 51-55: B. dussumieri

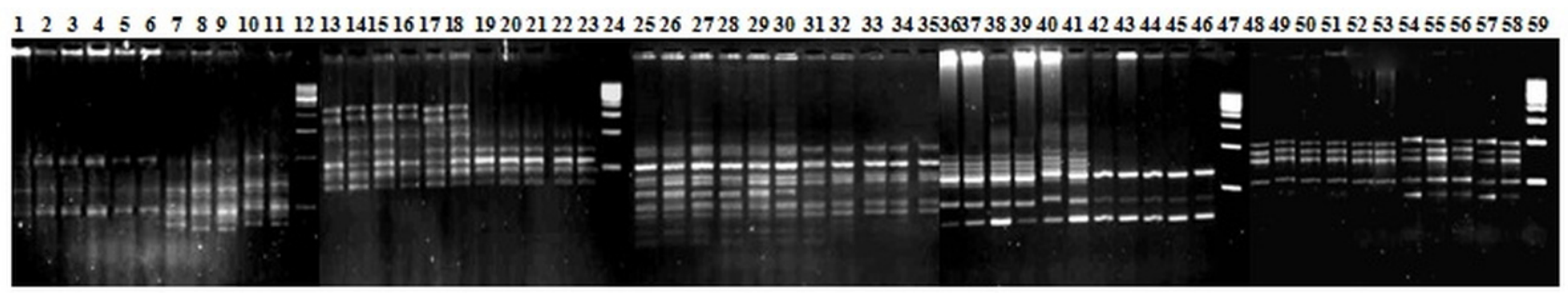

Fig. 1 (b). RAPD profiles generated with arbitrary primers in two mudskipper species with primer (An6-An10). Lanes 12, 24, 47 \& 59: 500-bp DNA ladder. Lanes 1-6; 13-18; 25-30; 36-41; 48-53: B. boddarti. Lanes 7-11; 19-23; 31-35; 42-46; 54-58: B. dussumieri 
Tab. 1. Number and size of the bands generated by ten RAPD primers and molecular weight of the diagnostic fragments in two mudskipper species

\begin{tabular}{|c|c|c|c|c|c|c|}
\hline \multirow{3}{*}{ RAPD primer } & \multirow{2}{*}{\multicolumn{2}{|c|}{ No. of fragments }} & \multicolumn{4}{|c|}{ Size range and diagnostic fragments (bp) } \\
\hline & & & \multicolumn{2}{|c|}{ B. boddarti } & \multicolumn{2}{|c|}{ B. dussumieri } \\
\hline & B. boddarti & B. dussumieri & Size range & Dia. frag. & Size range & Dia. frag. \\
\hline \multirow{4}{*}{ Anl } & \multirow{4}{*}{6} & \multirow{4}{*}{4} & \multirow{4}{*}{$1875-30$} & 1875 & \multirow{4}{*}{$1239-557$} & 1239 \\
\hline & & & & 1290 & & 1044 \\
\hline & & & & 585 & & 841 \\
\hline & & & & 30 & & 557 \\
\hline \multirow{4}{*}{ An2 } & \multirow{4}{*}{6} & \multirow{4}{*}{3} & \multirow{4}{*}{$1516-73$} & 1516 & \multirow{4}{*}{$2103-575$} & 2103 \\
\hline & & & & 1159 & & 1539 \\
\hline & & & & 357 & & 575 \\
\hline & & & & 73 & & \\
\hline \multirow{6}{*}{ An3 } & \multirow{6}{*}{7} & \multirow{6}{*}{4} & \multirow{6}{*}{$2113-70$} & 2113 & \multirow{6}{*}{$1440-70$} & 1440 \\
\hline & & & & 1391 & & 1034 \\
\hline & & & & 1002 & & 638 \\
\hline & & & & 866 & & \\
\hline & & & & 598 & & \\
\hline & & & & 87 & & \\
\hline \multirow{7}{*}{ An 4} & \multirow{7}{*}{6} & & & 1113 & & 1254 \\
\hline & & & & 849 & & 971 \\
\hline & & & & 678 & & 700 \\
\hline & & 7 & $1113-308$ & 515 & 1254-109 & 539 \\
\hline & & & & 414 & & 414 \\
\hline & & & & 308 & & 224 \\
\hline & & & & & & 109 \\
\hline & & & & 887 & & 1170 \\
\hline & & & & 736 & & 867 \\
\hline An5 & 5 & 4 & $887-66$ & 576 & $1170-514$ & 760 \\
\hline & & & & 251 & & 514 \\
\hline & & & & 66 & & \\
\hline & & & & 1056 & & 1022 \\
\hline & & & & 739 & & 664 \\
\hline $\mathrm{An} 6 \mathrm{C}-\mathrm{C}$ & 6 & 3 & 1056.229 & 645 & $1022-462$ & 463 \\
\hline An6 & 6 & 3 & $1056-329$ & 505 & $1022-463$ & \\
\hline & & & & 375 & & \\
\hline & & & & 329 & & \\
\hline & & & & 964 & & 2500 \\
\hline An7 & 5 & 7 & $1509-757$ & & $2500-757$ & 1982 \\
\hline & & & & & & 926 \\
\hline An8 & 6 & 7 & $1246-365$ & - & $1246-365$ & 603 \\
\hline & & & & 1256 & & 1418 \\
\hline & & & & 968 & & 1293 \\
\hline$A n 9$ & 3 & 6 & & 746 & & 1199 \\
\hline AnY & 3 & 0 & $1256-746$ & & $1418-720$ & 1120 \\
\hline & & & & & & 921 \\
\hline & & & & & & 720 \\
\hline & & & & 1077 & & 1058 \\
\hline An10 & 5 & 4 & $1077-345$ & 923 & $1058-547$ & 942 \\
\hline & & & & 345 & & \\
\hline
\end{tabular}

Although there was some variation observed between individuals within the species, most of the bands were not variable among different individuals of a given species. In- tra-species genetic variation was also detected in these two species (Tab. 2), but the level of polymorphism was low. The RAPD profile of each species was unique in terms of 
142

Tab. 2. Overall observed number of alleles (Na), Effective number of alleles (Ne), Nei's (1973) gene diversity (H), Shannon's Information index (I)

\begin{tabular}{ccccc}
\hline Species & $\mathrm{Na}$ & $\mathrm{Ne}$ & $\mathrm{H}$ & $\mathrm{I}$ \\
\hline B. boddarti & $1.0337 \pm 0.1815$ & $1.0196 \pm 0.1199$ & $0.0116 \pm 0.0066$ & $0.0175 \pm 0.0079$ \\
B. dussumieri & $1.0112 \pm 0.1060$ & $1.0110 \pm 0.1037$ & $0.0056 \pm 0.0024$ & $0.0077 \pm 0.0029$ \\
Overall & $1.8652 \pm 0.3435$ & $1.8377 \pm 0.3590$ & $0.4219 \pm 0.0765$ & $0.5874 \pm 0.0422$ \\
\hline
\end{tabular}

numbers and positions of bands. The inter-specific genetic similarity and distance are presented in Tab. 2. The genetic identity and distance between $B$. boddarti and B. dussumieri was $0.1662,1.7943$ respectively (Tab. 3 ).

Tab. 3. Nei's (1978) genetic identity (above diagonal) and genetic distance (below diagonal) of two mudskipper species

\begin{tabular}{ccc}
\hline & B. boddarti & B. dussumieri \\
\hline B. boddarti & ${ }^{* * * * *}$ & 0.1662 \\
B. dussumieri & 1.7943 & ${ }^{* * * * *}$ \\
\hline
\end{tabular}

\section{Genetic diversity}

The overall observed and expected polymorphic loci in B. boddarti and B. dussumieri is given in Tab. 3. The genetic diversity $(\mathrm{H})$ in $B$. boddarti was more $(0.0116$ $\pm 0.0066)$ than in B. dussumieri $(0.0056 \pm 0.0024)$. The UPGMA- neighbour joining tree (Fig. 2) grouped the two species into separate clusters emphasizing the distinct species status of $B$. boddarti and $B$. dussumieri.

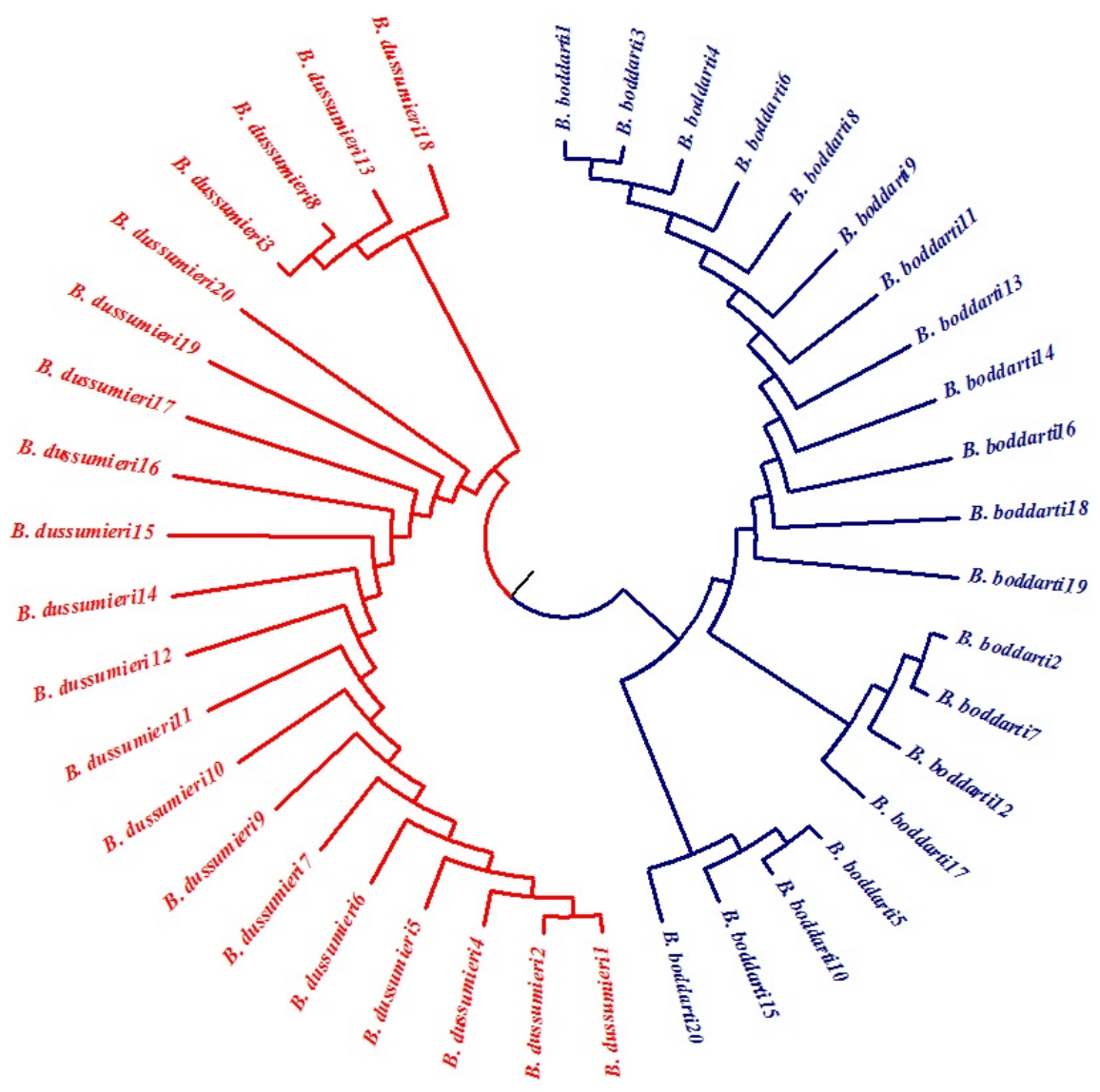

Fig. 2. Dendrogram Based Nei’s (1978) Genetic distance: Method = UPGMA -Modified from NEIGHBOR procedure of PHYLIP Version 3.5
This is the first report on the use of RAPD markers for studying genetic variation genetic diversity in this mudskipper species. The low levels of within-species genetic variation exhibited in $B$. dussumieri due to their less population for long period of time with in a limited area. This is an indication of possible high rate of inbreeding in $B$. dussumieri within less effective population size. Relatively higher levels of intraspecific genetic variation exhibited in B. boddarti (Tab. 2) may be due to comparatively higher effective population size. The RAPD profiles generated here for each species can be used for systematic inference. The phylogenetic tree obtained from the RAPD data emphasizing the distinct species status of $B$. boddarti, and $B$. dussumieri. (Fig. 2).

The genetic similarity between $B$. boddarti and $B$. dussumieri in this study was 0.1662 . Whereas, the interspecies genetic similarity was high (0.336) in Indian major 
carp and Tilapia by RAPD analysis (Barman et al., 2003; Dinesh et al., 1996; Eknath and Doyle, 1990). Similar to this present study, RAPD assay has been used to construct phylogenetic trees for resolving taxonomic problems in many organisms (Bardakci and Skibinski, 1994; Greef and Triest, 1999). The genetic distance is more between genus than between species and the hypothesis is also proved in this study by this marker. Same type of work also proved in earlier studies in Indian major carps (Barman et al., 2003).

Despite some limitations, the RAPD analysis can be used effectively for initial assessment of genetic variation among fish species, particularly in mudskippers for which very little genetic information is available now. This study represents a first step towards the generation of DNA markers for purposes, such as species diagnosis, detection of molecular markers linked to economic traits, assessment of genetic diversity and studies on molecular systematics. Further studies with other molecular markers such as microsatellite, allozyme, D-loop haplotype, $\mathrm{COI}$ and $\mathrm{Cyt} b$ gene sequences are essential to clarify and confirm the genetic relationships among all Indian mudskipper species.

\section{Acknowledgements}

The authors would like to thank The Director, CAS in Marine Biology and The Authorities of Annamalai University for the encouragement and facilities.

\section{References}

Bardakci F, Skibinski DOF (1994). Application of the RAPD technique in tilapia fish: species and subspecies identification. Heredity 73:117-123.

Barman HK, Barat A, Bharat M, Yadav, Banerjee S, Meher PK, Krishna Reddy PVG, Jana RK (2003). Genetic variation between four species of Indian major carps as revealed by random amplified polymorphic DNA assay. Aquaculture 217:115-123

Dinesh KR, Lim TM, Chua KL, Chan WK, Phang VPE (1993). RAPD analysis: an efficient method of DNA fingerprinting in fishes. Zool Sci 10:849-854.

Dinesh KR, Lim TM, Chua KL, Chan WK, Phang VPE (1996). Genetic variation inferred from RAPD fingerprinting in three species of tilapia. Aquac Int 4: 19-30.

Elo K, Ivanoff S, Jukka A, Vuorinen JA, Piironen J (1997). Inheritance of RAPD markers and detection of interspecific hybridization with brown trout and Atlantic salmon. Aquaculture 152:55-56.

Eknath AE, Doyle RW (1990). Effective population size and rate of inbreeding in aquaculture of Indian major carps. Aquaculture 85:293-305.

Felsenstein J (1993). PHYLIP (Phylogeny Inference Package), Version 3.5, Distributed by the author, University of Washington, Seattle.

Graham JB (1997). Air-breathing fishes: evolution, diversity and adaptation. San Diego, Academic Press.

Greef BD, Triest L (1999). The use of random amplified polymorphic DNA (RAPD) for hybrid detection in Scirpus from the river Schelde (Belgium). Mol Ecol 8:379-386.

Hardys H, Balick M, Schierwater B (1992). Applications of random amplified polymorphic DNA (RAPD) in molecular ecology. Mol Ecol 1: 55-63.

Harris VA (1960). On the locomotion of the mudskipper Periophthalmus koelreuteri (Pallas): Gobiidae. Proc Zoo Soc Lon 134:107-35.

Hillis DM, Moritz C (1990). Molecular Systematics, Sinauer Associates, Sunderland, MA., USA.

Maniatis T, Fritsch EF, Sambrook J (1982). MolecularCloning: A Laboratory Manual. Cold Spring Harbor, NY, Cold Spring Harbor Laboratory Press.

Murdy EC (1989). A taxonomic revision and cladistic analysis of the Oxudercine gobies (Gobiidae:Oxudercinae). Rec Aust Mus 11:1-93.

Nei M (1978). Estimation of average heterozygosity and genetic distance from a small number of individuals. Genetics 89:583-590.

Nei M, Li WS (1979). Mathematical model for studying genetic variation in terms of restriction endonucleases. Proc Nat Acad Sci USA 76:5269-5273.

Parveen JE, Thangaraj M, Ajithkumar TT, Bhimba BV, Rajasekar M (2011). RAPD probe on genetic variation in damsel fishes (Family Pomacentridae) in Gulf of Mannar region. Asian J Exp Biol Sci 2(4):687-690.

Piper R (2007). Extraordinary Animals: An Encyclopedia of Curious and Unusual Animals. Greenwood Press, 320 p.

Ravi V (2005). Post-Tsunami studies on the mudskipper Boleopthalmus boddarti (Pallas, 1770) from Mudasalodai, Tamil Nadu, Southeast coast of India. J Int Goby Soc 4(1):9-17.

Sneath PHA, Sokal RR (1973). Numerical taxonomy (W. H. Freeman and Co., San Francisco, CA), 573 p.

Taggart JB, Hynes RA, Prodohal PA, Ferguson A (1992). A simplified protocol for routine total DNA isolation from salmonid fishes. J Fish Biol 40:963-965.

Welsh J, McClelland M (1990). Fingerprinting genomes using PCR with arbitrary primers. Nucleic Acids Res 18:72137218.

Williams DJ, Kazianis S, Walter RB (1998). Use of random amplified polymorphic DNA (RAPD) for identification of largemouth bass subspecies and their intergrades. Trans Am Fish Soc 127L: 825-832.

Williams JGK, Kubelik AR, Livak KJ, Rafalski JA, Tingey SV (1990). DNA polymorphisms amplified by arbitrary primers are useful as genetic markers. Nucleic Acids Res 18: 6531-6535.

Yeh FC, Yang RC, Boyle T (1999). POPGENE 32 - Version 1.31. Population genetics software, Hyperlink http://www. ualberta.ca/ fyeh/fyeh/ 